\title{
Maidens, Magic, and Manipulation: The Female Presence in Sir Thomas Malory's Morte Darthur
}

\author{
Karen Moloney
}

School of English, UCC

\section{Introduction}

The legends of King Arthur and the Knights of the Round Table are preeminent in medieval lore, as literary history celebrates these valiant knights on their illustrious quests; these crusades, however, were very often affected, or even entirely motived, by love, lust, or a damsel in distress. What of those women whom these knights loved and lost, or feared and fought? A distinctly male presence remains the primary focus of medieval literature; my work aims to explore how the dynamic of these medieval texts is influenced and motivated by the consequences of female endeavours, in terms of an autonomous feminine presence in the narrative world, and the authority with which this is presented. My focus lies primarily with an exploration of this female form in Sir Thomas Malory's Morte Darthur, a fifteenth-century text which presents the Arthurian world governed by the king and his renowned company of knights, based on the author's reworking of both French and English source materials, plus additional material original to Malory himself. My studies take the concept of King Arthur and his Round Table Knights as being the definitive symbol of the essence of chivalric society and all it represents in terms of nobility, virtue and courage-indeed, as being a vehicle for the portrayal of the ultimate paragon of masculinity-and call it into question, as it is the actions of these men, and the consequences of their behaviours, which indicate the beginning of the unravelling of this society, and its eventual destruction as it essentially implodes under the weight of its own responsibility. My work examines the role of the female within this narrative dynamic, with specific regard to the accountability of women in the eventual failure of masculinity, and following from that, of society, in the text.

\section{The World of the Author and the World of the Text}

Who, then, were the women who populated the reality of the author's world? My research begins with an examination of the social positioning of the female in the fifteenth century, in order to be able to make an effective comparison with the portrayal of women 
in medieval literature. The analysis of the feminine presence in both a historical and literary context paves the way for a study of the specific depiction of the female in her various forms in the Morte Darthur, in comparison with this contemporary interpretation. As publisher, William Caxton's Prologue to the narrative presents the text to his audience in a very specific fashion, addressing both "lordes and ladyes", clearly denoting the intended recipients of this text to be both male and female. While fifteenth-century England was a patriarchal society ruled by male dictates, research has ascertained the influence of the aristocratic female of the time, in possession of land and independent wealth which awarded a certain economic and social authority. Similarly, the world of the Arthurian court is a predominantly male sphere, where masculinity reigns supreme; there exists, however, as in Malory's own surroundings, a demographic of women in possession of a certain authority which affords them social influence-though it may be exerted in the most subtle and understated of ways. An exploration of the actuality of the circumstances in which Malory wrote offers a platform for a more comprehensive study of the world of the text he created, while a knowledge of the similarities between the two realms presents today's reader with a sense of the social circumstances and psychological placement of the audience into which this text would have been received, and their ability to identify with it as such.

\section{The Feminine Presence in Medieval Literature}

Having established the social and economic positioning of women in society at the time, and therefore gained an understanding of the audience through which such material would have been circulated, my research goes on to provide an analysis of the manner in which the portrayal of women in fifteenth-century literature draws from the social reality of the time, with a detailed exploration of texts such as Floris and Blauncheflur, Havelok the Dane, Bevis of Hampton, and Guy of Warwick. These texts precede Malory, dating from the thirteenth and fourteenth centuries, demonstrating the literary positioning of the female in medieval romance while establishing the expectations of Malory's audience based on these well-recognised tales. These narratives are constructed based on both Anglo-Norman and French legends, and can be found in various manuscripts penned by different scribes. As such, particular authors are not established; the tales presumably originate from a male hand, in keeping with the literary tradition of the time. The objectification of the female in these texts emphasises and exaggerates the subordinate female; for example, Blauncheflur of Floris and Blauncheflur is repeatedly treated as a commodity throughout the progression of the narrative, traded and sold at the discretion of male authority. While her value is celebrated, it is a worth based on her commodification as opposed to being a recognition of her autonomous person. Similarly, the Middle English Havelok sees the rewarding of women through arranged marriages. These marriages are seen as a prize which will elevate the social standing of those ladies, in spite of the fact 
that they take all autonomous decision or self-governance from the women. Fundamentally, women's presence and behaviours are recognised, and rewarded, but in a very much defined manner which calls for their objectification in order for them to be recognised at all.

The fact that women have worth is not questioned, but the way in which this worth is measured is skewed toward the all-encompassing judgement of the male; virginity, for example, is seen as being a worthy prize and a valuable commodity for a woman to hold, making her all the more precious in the male market. While these compliments may seem to be somewhat back-handed in essence, in terms of their usefulness to society at large and men in particular, women are applauded for certain virtues seen to be definitively feminine, such as talents in the arts, healing capabilities, emotional strength and a nurturing nature. The scope for discussion here is vast, as different feminine qualities are highlighted while women fulfil their various roles; the feminine is very much present in these texts, and is often celebrated as such, but the fact remains that the female capacity for success in medieval narrative is almost always defined in terms of the male. Indeed, the presence of a female, taking an active role in a male/female dynamic, is usually an example of a woman's actions being utilised as a narrative tool in order to propel the narrative and position the dominant male in relation to the subsidiary woman.

\section{Female Authority in Le Morte Darthur}

How is Malory's Arthurian world influenced by these women, who exist within the delineations of social expectation? The female may not seem to be a prominent presence in the world of medieval literature, following from the patriarchal strictures laid in place by the reality of fifteenth-century English society. As evidenced, however, while their influence may be subtle, it is absolutely present, and actively so, as becomes extremely clear in a study of Malory's Arthurian kingdom. Here, the feminine maintains a constant presence in the world of the text, although it is not necessarily always a positive one. My research examines the role of women in Malory's text as being perhaps the most dangerous threat to the survival of the chivalric knight, through the elements of disguise, trickery, and sexual manipulation. The theory underlying the beliefs of the true chivalric knight, as outlined in the Pentecostal Oath to which all Knights of the Round Table swear their allegiance, assumes a fundamental respect towards the female, while ensuring the male retains authority in her protection. A closer exploration of the boundaries of the male/female dynamic in Le Morte Darthur, however, indicates the possibility of the balance of power being tilted in favour of the supposedly fragile woman. The very concept of chivalry is rooted in the protection of the vulnerable female, yet the manipulative woman may harness this perception of her sexuality in order to twist it to her advantage, and manipulate these knights who are ruled by their moral integrity. 
As such, the idea of emotional control is a powerful one, based on the paradox that the vulnerability of the female places women in a position where they are subject to men, yet because of this perceived fragility, they retain a great deal of power and influence in chivalric society, where knights are bound to protect. This is used to the detriment of various knights throughout the work, including Lancelot, who is driven to sheer madness as a result of feminine manipulation. Even Merlin, who is in possession of a supernatural knowledge, succumbs to the temptations of lust to the extent that his obsession leads him to be thwarted by the woman who is the recipient of his unwelcome attentions. While the chivalric world demands the utmost respect for the protection of the female, in doing so it allows a woman with dubious aspirations an arena in which to exploit and beguile, to suit her own ends.

In keeping with the Pentecostal Oath, respect for bodily integrity is of paramount importance to the concept of chivalry. Knights are sworn to protect and preserve the physical purity of the vulnerable female, yet this preservation remains equally important in terms of masculine chivalric integrity. Lines between enforced sexual aggression and persistent seduction can often be blurred, as can the element of consensual relations, which reflects realistically on the laws of Malory's own social reality. Sexual possession in the text, however, is a treacherous area in terms of both the masculine and the feminine; for example, while Elaine of Astolat dies for her unrequited love of Lancelot, Lancelot himself suffers at the hands of Elaine of Corbin, who employs both worldly deceits and otherworldly enchantments in order to seduce him, leading to his consequent madness.

Sexual integrity and physical possession of a lover are therefore extremely powerful tools, particularly when viewed in terms of the empowering element of virginal purity. Virginity as a valuable commodity is presented time and time again in medieval literature, and more powerfully than ever in Malory's Morte Darthur, where, for example, Perceval's sister's virginal state allows her to sacrifice her blood, the purity of which saves the life of a terminally diseased lady. Here, the precious nature of virginity is manifest, but this is not a uniquely feminine attribute in Malory's text; in relation to the male, succumbing to the temptations of fleshly gratification will irreparably tarnish a knight's virtue, leaving him unequipped to achieve that ultimate goal of the Holy Grail. Lust and sexual temptation arise repeatedly as obstacles facing the chivalric Knights of the Round Table, determining the fact that rape and sexual aggression therefore hold significant consequences for both parties, male and female, with feminine sexuality proving just as much of a threat to male integrity, as the threat of rape is to the physically vulnerable woman.

Malory's conscious awareness of this paradox of female fragility is debatable, bearing in mind that he made certain changes from his source material which encouraged the notion of feminine virtue, such as his reluctance to acknowledge a physical relationship between Lancelot and Guinevere. These source alterations tend to emphasise the concept of the vulnerability of the female on the whole, which in turn highlights the paradox of the 
power afforded by this perceived fragility. This is not to say that Malory's Morte Darthur exclusively presents the female as a destructive force; the text does present women of admirable stature demonstrating the best of feminine virtue. In terms of influence in the narrative, however, the dynamic which exists because of the male perception of femininity is most effectively examined in terms of the exploitation of this masculine consciousness.

\section{Conclusion}

In essence, my research aims to comprehensively explore the concept of Malory's treatment of the female in comparison with his literary contemporaries and the actuality of the woman in society of the time. This encapsulates the fact that although the majority of the active primary roles in Malory's text are tilted towards the male characters, the dynamic of the narrative is hugely influenced and motivated by the consequences of female endeavours in an intricate subtext. My work incorporates the presentation of the female in this patriarchal domain as being vulnerable and in need of protection as she simultaneously manipulates this perceived fragility to challenge masculine control, with the intent of presenting an innovative interpretation of feminine authority in an exploration of the physical, intellectual and emotional placement of women in Arthurian literature.

With gratitude to my supervisors, Dr. Andrew King and Dr. Kenneth Rooney. 